УДК 551.4.042+551.4.022+559.462

\title{
СОВРЕМЕННЫЙ ЭОЛОВЫЙ МОРФОЛИТОГЕНЕЗ: ИЗУЧЕННОСТЬ, РЕГИОНАЛЬНЫЕ ПРОЯВЛЕНИЯ
}

\author{
Евсеева Нина Степановна ${ }^{1}$, \\ nsevseeva@yandex.ru
}

\author{
Язиков Егор Григорьевич², \\ yazikoveg@tpu.ru
}

\author{
Квасникова Зоя Николаевна 1 , \\ zojkwas@rambler.ru
}

\section{Батманова Антонина Сергеевна ${ }^{1}$, tonu6ka@yandex.ru}

\author{
Бучельников Виктор Сергеевич2, \\ victor.buchelnikov@yandex.ru \\ 1 Национальный исследовательский Томский государственный университет, \\ Россия, 634050, г. Томск, пр. Ленина, 36. \\ 2 Национальный исследовательский Томский политехнический университет, \\ Россия, 634050, г. Томск, пр. Ленина, 30.
}

\begin{abstract}
Актуальность исследования экзогенных процессов, в том числе дефляции, обусловлена как положительным, так и отрицательным воздействием их на природные компоненты и хозяйственную деятельность человека. Кроме того, не до конца выявлены особенности региональной миграции вещества при развитии этих процессов и интенсивность аккумуляции эолового наноса, его вещественный состав. Изучение факторов развития эрозии и дефряции в геосистемах юго-востока Томской области показало, что природные и социально-экономические факторы региона благоприятны для развития эоловых процессов.

Цель: оценка интенсивности аккумуляции эолового осадка и его вещественного состава в ландшафртах юго-востока Томской области.

Объекты: природные и антропогенные комплексы Томь-Яйского междуречья в пределах бассейна р. Басандайки - правого притока р. Томи.

Методы: полевые (маршрутные) наблюдения с отбором проб, лабораторные и аналитические исследования.

Результаты многолетних наблюдений показали, что в холодный период года эоловые процессы в агроландшасртах юговостока лесной зоны Западно-Сибирской равнины проявляются ежегодно, но с разной степенью интенсивности. Наиболее активно они развиваются в малоснежные годы. В гранулометрическом составе эолового наноса преобладает пыль, в минералогическом - квари и мусковит. Эоловые отложения содержат значительное количество элементов питания растений гумуса - до 10 \%. Не исключая притока атмосферных выпадений из других регионов, считаем, что основная масса эолового осадка ключевых участков (юго-восток Томской области) в холодное время года имеет местное происхождение, об этом свидетельствует большое сходство его гранулометрического, химического и минералогического состава с почвами региона
\end{abstract}

\section{Ключевые слова:}

Десрляция, эоловые процессы, Томская область, Томь-яйское междуречье, пылеуловитель, пашня.

\section{Введение}

В настоящее время особую актуальность в исследованиях наук о Земле приобретают пространственно-временные сравнения - стационарные, полустационарные наблюдения и их увязка с динамикой географической оболочки; они являются логическим продолжением локального и регионального направлений исследования природы и выступают элементами единой системы мониторинга окружающей среды.

Одно из таких направлений - изучение экзогенных процессов рельефообразования. Определение скоростей их развития, интенсивности седиментации современных осадков (озерных, аллювиальных, морских, эоловых и др.) рано или поздно приводят исследователя к мысли о потоках вещества в географической оболочке. Концепция потоков создана трудами многих ученых - В.И. Вернадского, Б.Б. Полынова, В.А. Ковды, М.А. Глазовской, Г.В. Добровольского,
А.И. Перельмана, Н.Ф. Глазовского, Н.С. Касимова, В.П. Чичагова и др. Одними из активных экзогенных процессов, создающих потоки вещества, являются эоловые, основы изучения которых заложены Н.М. Пржевальским, В.А. Обручевым, П.А. Гутковским, Д.В. Наливкиным и другими исследователями.

В современную эпоху эоловые процессы распространены почти во всех природных зонах, но наиболее интенсивно они развиваются в степях, полупустынях и пустынях. В аридной и семиаридной зонах эти процессы создают эоловые потоки песка, пыли, аэрозолей и солей в приземном слое атмосферы. По сравнению с водными потоками эоловые потоки имеют большой фронт распространения в ширину, длину и высоту, что связано с огромными масштабами площади их контакта с сушей, акваторией и атмосферой. Развитие эоловых процессов и создаваемые ими потоки оказывают как положительное, так и от- 
рицательное влияние на природные компоненты и деятельность человека. Например, почвы гор СьерраНевада (Калифорния, США) бедны фосфором, но благодаря тому, что эоловые потоки приносят из пустыни Гоби в том числе и этот элемент на склоны гор, здесь произрастают густые леса, среди которых и знаменитые секвойи [1]. Но эоловые потоки вместе с пылью переносят и патогенные микроорганизмы, вызывающие болезни, различные токсичные химические элементы, среди которых и радиоактивные [2]. Экономический ущерб от эоловых процессов очень велик, он обусловлен различными факторами, среди которых наиболее значимые: снижение почвенного плодородия; выдувание и засыпание сельскохозяйственных культур, ирригационных каналов, дорог; нарушение работы линий электропередач, трубопроводов и др. Основная часть финансовых убытков от эоловых процессов приходится на долю дефляции. Приближенно величину ущерба от эоловой деятельности можно оценить в 5-7 млрд долл./год [3].

Вследствие вышесказанного, изучению эоловых процессов уделяется большое внимание как в нашей стране, так и за рубежом [4-9]. Исследования эоловых процессов многоаспектны и посвящены факторам их развития, интенсивности и аккумуляции выпадающих из атмосферы осадков, их гранулометрического и химического составов, пылевой минерало- гии, влиянию на компоненты ландшафта; моделируются процессы ветровой эрозии. Также проводятся работы по выявлению очагов возникновения и географического распространения эоловых морфодинамических процессов в аридном и семиаридных поясах Евразии, связанных с пространственным положением полярного фронта, разделяющего умеренный (полярный) и тропический воздух. Рассматривается влияние динамики атмосферы (скорость и повторяемость ветров различных направлений) на интенсивность и пространственную упорядоченность эоловых процессов [10-12].

На равнинах умеренного пояса Евразии выделены три экзогенно-динамические зоны современной дефляции и потоки эоловой миграции вещества (рис. 1). В азиатском регионе зона выдувания более динамична и растянута в пространстве, поскольку возникновение этого явления связано с фронтальными процессами [12]. Выдувание и транзит пыли происходит в основном с подстилающей поверхности засушливых и сухих степей Ишим-Иртышского и ОбьИртышского междуречий, а выпадение пыли приходится на лесные районы юго-восточной и центральной частей Западной Сибири. Установлено, что современные распаханные степи наряду с аридными ландшафтами умеренного и тропического поясов также активная зона развевания вещества.

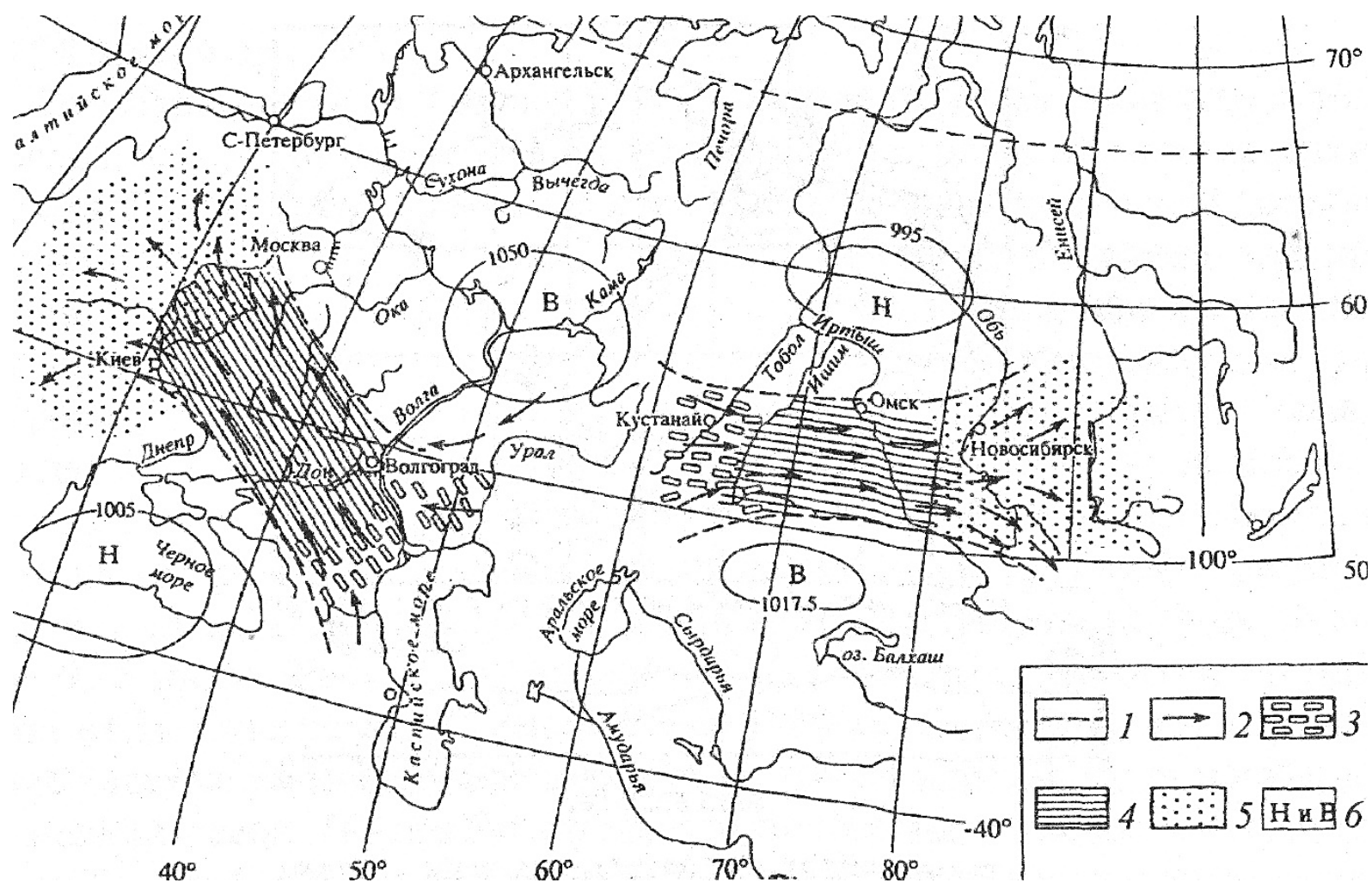

Pис. 1. Экзодинамические зоны современной дефляции и потоки эоловой миграции вещества на равнинах умеренного пояса Евразии [12]: 1 - границы областей активной дефляции, 2 - направление воздушного потока при сильных пыльных бурях; зоны: 3 - преобладающего вылувания, 4 - переноса, локального выдувания и аккумуляции, 5 - накопления эолового материала; 6 - области низкого и высокого давления

Fig. 1. Exodynamic zones of modern deflation and aeolian migration fluxes of material on Eurasian temperate zone lowlands [12]: 1 - active deflation zone edges; 2 - the direction of moving air under the strong dust-storm conditions; zones: 3 - predominant deflation; 4 - migration, local deflation, and accumulation; 5 - aeolian material accumulation; 6 - low and high-pressure zones 
Изучение глобальных потоков и миграции минерального вещества на уровне межгеосферного обмена позволило оценить массу ежегодного выноса пыли. Согласно этим оценкам в период доантропогенного воздействия на литосферу ежегодный вынос пыли в атмосферу не превышал 0,05 т/га. По разным оценкам общемировое продуцирование пыли достигает 0,34 т/га [12]. Таким образом, с доантропогенного периода продуцирование пыли увеличилось почти в 7 ра3: от 50 до 340 кг/га в год.

Осаждение пыли на земную поверхность оказывает влияние на вещественный состав рыхлых отложений. В связи с чем большой интерес представляет вопрос о роли этих осадков в формировании лессовых пород, поскольку в зонах выдувания происходит дефляция почвенного покрова, а в зонах аккумуляции накопление эолового наноса. Исследования В.Т. Трофимова и др. показали влияние эоловых процессов на формирование лессовых пород во время плейстоценовых оледенений и в современную эпоху. В результате анализа разнообразия климатов и ландшафтов Азии и распространения лессовых пород намечены две субширотные зоны: субтропическая пустынно-лессовая и умеренная перигляциальнолессовая [13]. Последняя приурочена к умеренным широтам - примерно от $45^{\circ}$ с.ш. до $60^{\circ}$ с.ш., в ее пределах могут быть выделены провинции - ЗападноСибирская, Алтае-Саянская, юго-востока Сибири и Забайкалья.

В целом в изучении эоловых процессов достигнуты успехи, но есть и нерешенные вопросы, имеющие как теоретическое, так и практическое значение. Coгласно А.Н. Сажину и др. актуальными являются две проблемы: скорость эоловой планации и пространственная межгеосферная миграция вещества или направление перемещения минеральной взвеси при сильных пыльных бурях и ураганах, выпадение ее из двухфазового потока и аккумуляция на подстилающей поверхности [11]. М.Е. Бельгибаев отмечает, что еще не до конца известны биогеохимические процессы в атмосфере, морях, океанах и качественные изменения выпадающих из атмосферы осадков [14]. J.S. Munroe указывает на то, что в большинстве наблюдений, где было проведено изучение современного осаждения пыли, не были исследованы геохимия и минералогия пыли, что приводит к неопределенности в отношении ее источников [9]. Кроме того, не до конца изучено влияние эолового наноса на воды, почвы, растительность, а также особенности региональной миграции вещества при развитии этих процессов и интенсивность аккумуляции эолового наноса, его вещественный состав. Недостаточно исследованы названные проблемы и для лесной зоны юго-востока Западно-Сибирской равнины.

Изучение экзогенных процессов рельефообразования, в том числе факторов развития эрозии и дефляции в геосистемах юго-востока Томской области показало, что природные и социально-экономические факторы региона благоприятны для развития эоловых процессов.

Цель данной работы - оценка интенсивности аккумуляции эолового осадка и его вещественного состава в природных и антропогенных комплексах юговостока Томской области.

\section{Объект исследования}

Объектом исследования являются геосистемы Томь-Яйского междуречья в пределах бассейна реки Басандайка - правого притока р. Томи (рис. 2). Антропогенная трансформация ландшафтов региона способствует развитию эоловых процессов (дефляции, переноса и аккумуляции) в пределах агроландшафтов, на вырубках, гарях и других участках с активной хозяйственной деятельностью.

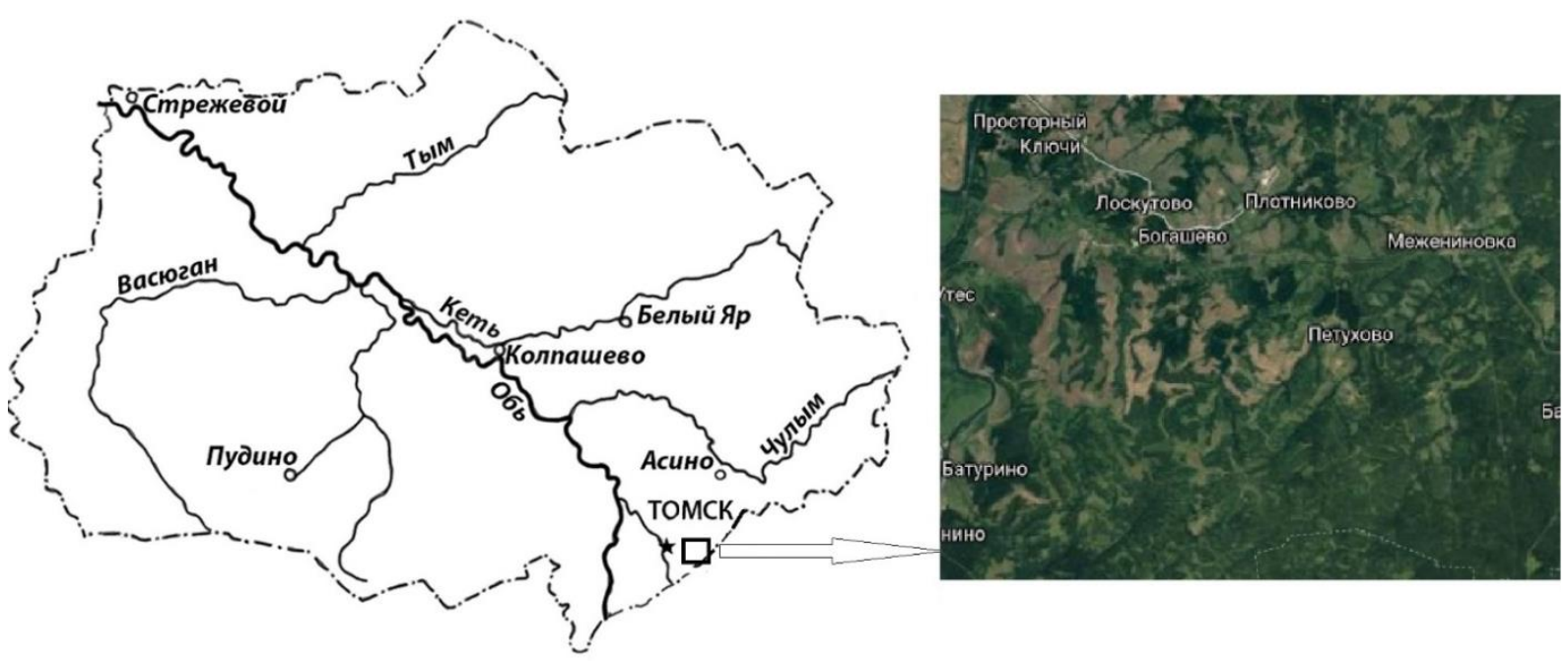

Рис. 2. Район исследования в пределах юго-востока Томской области (выделен в прямоугольник)

Fig. 2. Study area within the southeast of Tomsk region (highlighted by the rectangle) 
Таблица 1. Средняя и максимальная скорости ветра с учетом порывов по станции Томск [15], м/с

Table 1. Average and maximum wind speed with account for gusts at the Tomsk weather station [15], $\mathrm{m} / \mathrm{s}$

\begin{tabular}{|c|c|c|c|c|c|}
\hline Месяц/Month & $\begin{array}{c}\text { Средняя за 5 лет } \\
\text { Average for 5 years }\end{array}$ & $\begin{array}{c}\text { Абсолютный } \\
\text { максимум } \\
\text { Absolute maximum }\end{array}$ & Месяц/Month & $\begin{array}{c}\text { Средняя за 5 лет } \\
\text { Average for 5 years }\end{array}$ & $\begin{array}{c}\text { Абсолютный } \\
\text { максимум } \\
\text { Absolute maximum }\end{array}$ \\
\hline январь/January & 7,2 & 17 & июль/July & 7,1 \\
\hline февраль/February & 7,6 & 24 & август/August & 7,2 & 17 \\
\hline март/March & 7,1 & 14 & сентябрь/September & 7,3 \\
\hline апрель/April & 8,9 & 19 & октябрь/October & 7,4 \\
\hline май/May & 9,1 & 18 & ноябрь/November & 7,9 & 13 \\
\hline июнь/June & 8,2 & 14 & декабрь/December & 8,7 \\
\hline
\end{tabular}

Изучаемый район входит в умеренную перигляциально-лессовую зону распространения лессовых пород $\left(45^{\circ}-60^{\circ}\right.$ с.ш.) [13]. Мощность лессовых пород в пределах междуречья изменяется от 0,8 до 13 м. Бассейн р. Басандайки относится к району развития сильного ветра, где его скорость во все месяцы года достигает 20-34 м/с. Ветер вблизи земной поверхности характеризуется турбулентностью (порывистостью), т. е. его скорость меняется во времени и пространстве. Во время порывов средняя и максимальные скорости ветра за 10 минут изменяются в течение года от 7,1 до 24 м/с (табл. 1). Частота порывов значительна, например, при средней скорости ветра $4 \mathrm{~m} / \mathrm{c}$ в среднем наблюдается 5 порывов в минуту, а при $13 \mathrm{~m} / \mathrm{c}-85$ порывов [15]. Сильные и порывистые ветры производят дефляцию почв, особенно на наветренных и возвышенных участках пашни, вырубках и других территориях подверженных антропогенной деятельности.

Хозяйственное освоение земель исследуемой территории ведется с начала XVII в. Распашке подвергаются в основном серые лесные почвы и их подтипы, а также дерново-подзолистые, черноземы оподзоленные и выщелочные [16]. Почвы региона содержат большое количество пыли, что является одним из признаков их дефляционной опасности (до $80 \%$ ). Более подробно факторы развития ветровой эрозии изложены нами в работе [17].

\section{Фактический материал, методы} и приемы исследования

Бассейн реки Басандайка площадью более 400 км² $^{2}$ один из наиболее освоенных в сельскохозяйственном отношении, расположен в центральной части ТомьЯйского междуречья и принят нами за фоновый исследуемый район. В его пределах выделены ключевые участки где проводятся полустационарные наблюдения за эоловыми процессами в течении 32 лет (с 1989 г.). Реализация цели исследования осуществлена на основе проведения следующих видов работ:

1) отбор проб из шурфов в снежной толще во время выполнения ежегодных маршрутных снегосъемок в микромасштабе (130 проб), что позволило определить интенсивность аккумуляции эолового наноса в снежной толще за период от образования устойчивого снежного покрова (в основном II-III декады октября) до времени его максимального накопления (I-II, реже III декады марта - начало апреля);

2) наблюдения за седиментацией эолового наноса во время снеготаяния, когда отбирались пробы с поверхности снега за разные отрезки времени после снегопа- да с площадок в $1 \mathrm{~m}^{2}$ и толщиной снега в 1-2 см по профилям длиной от 200-500 до 1200 м (113 проб);

3) наблюдения за аккумуляцией эолового наноса в пылеуловителях (с 2013 г.) по методу M. Reheis [6]. Пылеуловители размещались в разных элементарных природных и антропогенных комплекcax - на наветренных склонах пашни, в березовой и сосновой лесополосах, на кромке и в глубине кедрового леса (37 проб);

4) наблюдения за скоростью ветра на высоте 1 м над поверхностью земли на пашне анемометром АРИ49. Порывы ветра достигали в зимний и весенний периоды до 20-25 м/с;

5) определение химического состава (микроэлементов) (108 проб), макроэлементов-биогенов (C, N, P, гумуса) (35 проб) и гранулометрического состава (17 проб), эолового наноса, минералогического состава почв (6 проб) и атмосферных выпадений из пылеуловителей (2 пробы). Геохимический состав определялся с помощью аттестованной методики количественного атомного эмиссионного анализа (свидетельство № 08-47/200) в ЦКП «Аналитический центр геохимии природных систем», Томского государственного университета. Вещественный состав изучался методами оптической микроскопии, с помощью бинокулярного микроскопа Leica EZ4D, а также рентгенофазового анализа (РФА), на рентгеновском дифрактометре Bruker D2 Phaser, на базе учебно-научной лаборатории электронно-оптической диагностики МИНОЦ «Урановая геология» Томского политехнического университета;

6) определение показателя дефляционной опасности почв (ПДО) по методике М.Е. Бельгибаева [14].

\section{Результаты и их обсуждение}

Согласно А.Н. Сажину и др. [10] лесная зона юговостока Западно-Сибирской равнины - это область накопления эолового материала, выпадающего из потоков в атмосфере (рис. 1). Наши 32-летние наблюдения показывают, что на пашне дефляция, перенос и аккумуляция почвенных частиц происходят круглый год, но с разной степенью интенсивности.

Авторами данной работы определен показатель дефляционной опасности почв (ПДО) региона для верхних горизонтов почв $(0-10 ; 0-20$ см), он рассчитывается по отношению процентного содержания физической глины $(<0,01$ мм) и физического песка $(>0,01$ мм). Значения ПДО распределяются следующим образом: 0-0,3 - очень сильноподатливые; 
0,3-0,6 - сильноподатливые; 0,6-1,2 - среднеподатливые; 1,2-2,0 и более - слабоподатливые. Расчеты ПДО, проведенные по 49 пробам почв в бассейне р. Басандайки, отобранным в основном на пашне, показали, что $6,2 \%$ из них относятся к очень сильноподатливым; $26,5 \%$ - сильноподатливые, 57,1 \% - к среднеподатливым, и только 10,2 \% - к слабоподатливым [18]. Анализ полученных расчетов показывает, что около $33 \%$ почв пашни региона сильноподатливы к ветровой эрозии, а более $57 \%$ - среднеподатливые.

Исследованиями ряда ученых [19, 20] установлено, что движение выдутых ветром частиц почвы волнообразное и осуществляется путем перекатывания, скачками и во взвешенном состоянии. Основная масса мелкозема (до 95 \%) переносится ветром в приземном слое почвоветрового потока, толщина этого слоя по разным оценкам может достигать 40-50 см. По данным наших наблюдений во время порывов ветра со скоростью около $20 \mathrm{~m} / \mathrm{c}$ по поверхности снега скачками высотой до 40-50 см переносятся комочки почвы диаметром до 3 мм (возможно и более). Для поддержания пылеватых частиц во взвешенном состоянии достаточно скоростей ветра 2-3 м/с. При скоростях ветра более 15-16 м/с массовый перенос песка (песчаные бури), грунта, снега (но не пыли) может происходить в слое до 2 м от поверхности [19].

Авторами данной статьи выполнен значительный объем работ по определению интенсивности аккумуляции продуктов ветровой эрозии и их вещественного состава выпадающих из почвоветрового потока при перекатывании и сальтации, а также взвешенных частиц на высоте 2 м над поверхностью земли. Наиболее полно интенсивность седиментации эолового наноса, ее динамика и вещественный состав изучены нами на примере ветровой эрозии холодного периода года (октябрь-апрель) с выделением стадий: 1 - в период устойчивого залегания снежного покрова; 2 - во время снеготаяния. Рассмотрим полученные результаты по названным стадиям:

1. Зимняя ветровая эрозия наиболее активно развивается в малоснежные годы, когда на этот процесс сильно влияет мезо- и микрорельеф пашни на разных участках склонов. Наши наблюдения хорошо согласуются с исследованиями К.С. Кальянова: влияние рельефа выражается в изменении скорости ветра на разных участках склона [21]. На наветренных склонах и возвышенных участках пашни происходит увеличение скорости ветра, что приводит к образованию на них очагов дефляции. Наблюденные размеры таких очагов изменялись от долей квадратного метра до 3-4 га. Темная поверхность пашни подвергается морозному выветриванию, верхний слой почвы иссушается, становится рыхлым до глубины 5 см и более, сильные ветры разрушают почвенный покров, и в снежной толще появляются грязные прослойки. Наблюденное количество их достигает от 1 до 5-7 штук.

Интенсивность накопления эоловых осадков неравномерна, что объясняется возникновением на поверхности снега эоловой ряби, когда массовое движение частиц почвы во время эрозии при сравнительно небольших скоростях ветра происходит в форме волн, а вынос почвы сводится к перемещению этих волн. Этот факт подтверждается отборами проб по опорным профилям за 1989-2020 гг. Наиболее дефляционоопасной была малоснежная зима 2011-2012 гг., когда в снежной толще в понижениях рельефа накопилось до 1848 г/м² эолового осадка.

Многолетние наблюдения за седиментацией эолового осадка за период устойчивого залегания снежного покрова показали, что она неравномерна не только в пространстве, но и во времени и изменялась в сред-

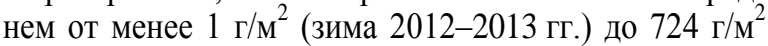
(зима 2011-2012 гг.) (по данным 96 проб). Полученные данные о массе эолового наноса в снежной толще позволили рассчитать среднесуточную величину аккумуляции (табл. 2)

Анализ таблицы показывает, что среднесуточная величина аккумуляции наноса в снежной толще варь-

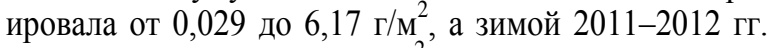
местами достигала 15,03 г/м². Это сопоставимо с аккумуляцией пыли после пыльных бурь в аридных ландшафтах: так, в Туркмении после 10-минутной

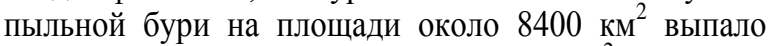

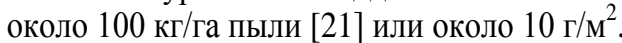

Наши 32-летние наблюдения показали, что можно выделить зимы слабого проявления ветровой эрозии, когда в снежной толще пашни накапливалось менее

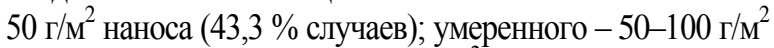

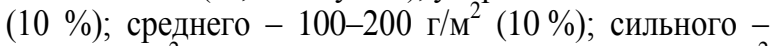

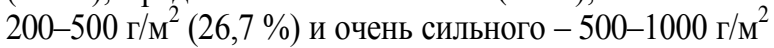
(10\% случаев). В кедровом лесу в снежной толще за указанный период времени содержание эолового осадка изменялось от 0,02 г/ $\mathrm{m}^{2}$ (зима 2005-2006 г.) до 18,8 г/м² (зима 2007-2008), а среднесуточная аккумуляция - доли грамма. В гранулометрическом составе эолового осадка в снежной толще агроландшафта преобладает пыль (табл. 3).

Таблица 2. Среднесуточная аккумуляция эолового материала в снежной толще (на примере ряда лет)

Table 2. Average daily aeolian material accumulation within the snow cover (the case of series of years)

\begin{tabular}{|c|c|c|c|c|}
\hline $\begin{array}{l}\text { Годы, зима } \\
\text { Years, winter }\end{array}$ & $\begin{array}{c}\text { Даты залегания устойчивого } \\
\text { снежного покрова и снегосъемки } \\
\text { Dates of stable snow covering and } \\
\text { snow survey }\end{array}$ & $\begin{array}{l}\text { Количе- } \\
\text { ство суток } \\
\text { Number of } \\
\text { days } \\
\end{array}$ & 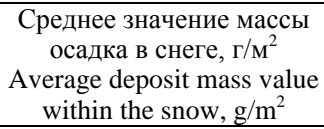 & $\begin{array}{c}\text { Среднее значение интенсивности } \\
\text { аккумуляции за сутки, г/м }{ }^{2} \\
\text { Average accumulation intensity } \\
\text { value per day, g/m }{ }^{2}\end{array}$ \\
\hline 1989-1990 & $31.10 .1989-25.03 .1990$ & 144 & 301,0 & 2,1 \\
\hline $1992-1993$ & $27.10 .1992-24.03 .1993$ & 147 & 4,24 & 0,03 \\
\hline $2002-2003$ & $15.10 .2002-15.03 .2003$ & 150 & 550,0 & 3,7 \\
\hline 2004-2005 & 16.10.2004-11.03.2005 & 145 & 80,1 & 0,6 \\
\hline $2011-2012$ & $29.10 .2011-02.03 .2012$ & 123 & 752,4 & 6,1 \\
\hline 2014-2015 & $16.10 .2014-14.03 .2015$ & 148 & 143,5 & 0,9 \\
\hline 2016-2017 & 15.10.2016-15.03.2017 & 150 & 22,0 & 0,15 \\
\hline 2018-2019 & $26.10 .2018-16.03 .2019$ & 130 & 23,2 & 0,18 \\
\hline
\end{tabular}


Таблица 3. Гранулометрический состав отложений и содержание в них биогенов

Table 3. Grain size distribution of deposits and content of organic matter

\begin{tabular}{|c|c|c|c|c|c|c|c|c|c|c|c|c|c|}
\hline \multirow[b]{2}{*}{$\begin{array}{l}\text { Тип отложений } \\
\text { Туре of deposit }\end{array}$} & \multirow[b]{2}{*}{$\begin{array}{c}\text { Гумус } \\
\text { Humus, } \\
\%\end{array}$} & \multirow[b]{2}{*}{ C, $\%$} & \multirow[b]{2}{*}{$\mathrm{Ca}^{2+}$} & \multirow[b]{2}{*}{$\mathrm{Mg}^{2+}$} & \multirow[b]{2}{*}{$\mathrm{N}, \%$} & \multirow[b]{2}{*}{$\mathrm{P}, \%$} & \multirow{2}{*}{ 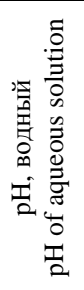 } & \multicolumn{6}{|c|}{$\begin{array}{l}\text { Гранулометрический состав } \\
\text { Grain size }\end{array}$} \\
\hline & & & & & & & & $\begin{array}{c}n \\
n \\
0 \\
\vdots \\
0 \\
-1\end{array}$ & $\begin{array}{l}n \\
0 \\
0 \\
\vdots \\
n \\
n \\
0\end{array}$ & $\begin{array}{c}0 \\
0 \\
0 \\
\vdots \\
0 \\
0 \\
0\end{array}$ & $\begin{array}{c}n \\
0 \\
0 \\
\vdots \\
\vdots \\
0 \\
0\end{array}$ & $\begin{array}{c}\overline{8} \\
0 \\
\vdots \\
\vdots \\
0 \\
0 \\
0\end{array}$ & $\begin{array}{l}\overline{8} \\
8 \\
\dot{8}\end{array}$ \\
\hline $\begin{array}{l}\text { Осадок из снежной толщи } \\
\text { Snow mass sediment }\end{array}$ & $1,0 \ldots 4,1$ & $0,9 \ldots 2,1$ & До 17,9 & 4,7 & 0,1 & До 0,2 & 6,4 & 0,9 & 17,1 & 40,9 & 6,5 & 13,7 & 20,8 \\
\hline $\begin{array}{l}\text { Эоловый нанос } \\
\text { с поверхности снега } \\
\text { Aeolian deposit } \\
\text { from the snow surface }\end{array}$ & $1,7 \ldots 4,5$ & $1,0 \ldots 2,2$ & До 17,8 & 8,9 & 0,3 & 0,4 & 5,6 & 1,9 & 19,5 & 38,9 & 9,9 & 11,2 & 18,6 \\
\hline
\end{tabular}

Таблица 4. Вариации интенсивности аккумуляции эолового осадка на поверхности снега за разные отрезки времени на примере ряда лет

Table 4. Variations in the intensity of aeolian deposits accumulation on the snow surface over different time periods (the case of a number of years)

\begin{tabular}{|c|c|c|}
\hline $\begin{array}{l}\text { Период наблюдений } \\
\text { Observation period }\end{array}$ & $\begin{array}{l}\text { Масса осадка на поверхности снега, } г / \mathrm{M}^{2} \\
\text { Mass of deposit on the snow surface, } \mathrm{g} / \mathrm{m}^{2}\end{array}$ & 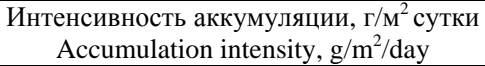 \\
\hline 1990: 25.03-08.04 & $18,2 \ldots 102,4$ & $1,3 \ldots 7,31$ \\
\hline 1993: 16.03-24.03 & $0,13 \ldots 7,84$ & $0,02 \ldots 0,98$ \\
\hline $\begin{array}{c}\text { 2004: 08.03-21.03 } \\
\text { 20.03-21.03 }\end{array}$ & $\begin{array}{c}54,48 \ldots 209,9 \\
\text { до } 23,6\end{array}$ & $4,54 \ldots 17,49$ \\
\hline $\begin{array}{l}\text { 2015: } 14.03-11.04 \\
11.04-25.04\end{array}$ & $\begin{array}{c}0,04 \ldots 36,51 \\
3,9 \ldots 320,0\end{array}$ & $\begin{array}{l}0,001 \ldots 1,30 \\
0,28 \ldots 22,86\end{array}$ \\
\hline 2019: 18.04-27.04 & $1,22 \ldots 10,64$ & $0,13 \ldots 1,18$ \\
\hline
\end{tabular}

2. Из табл. 4 видно, что в отдельные годы во время снеготаяния на пашне случаются местные «пыльные бури», когда за короткие отрезки времени на поверхность снега выпадало до 74,83 г/м² эолового осадка. Например, весной 2002 г. за 3 суток выпало на снег до 224,5 г/м² осадка; в 1991 г. за 15 суток - до

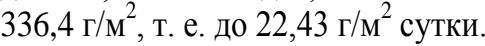

В гранулометрическом составе на поверхности снега также преобладает пыль (табл. 3). Минералогический состав осадка с поверхности снега аналогичен лессовидным суглинкам, подстилающей породе исследуемого района, и представлен преимущественно кварцем и полевыми шпатами. В эоловых осадках в снежной толще и на эоловых волнах содержание гумуса в пробах на пашне изменялось от 1,1 до 4,5 \%, $\mathrm{Ca}^{2+}$ - до 17,95; $\mathrm{N}$ - до 0,34 \% и др. (табл. 3). Сравнение среднего содержания микроэлементов (тяжелых металлов) в эоловых отложениях показывает близость их химического состава с литогенным субстратом верхних горизонтов почв пашни плакорных местоположений [22].

Как отмечает Л.Б. Аристархова и др., при скоростях ветра более 15-16 м/с массовый перенос песка (песчаные бури), грунта, снега (но не пыли) может происходить в слое до 2 м над поверхностью земли [19]. Частицы диаметром менее 0,05 мм, оторванные от поверхности, под влиянием атмосферной диффузии могут находится во взвешенном состоянии длительное время. При падении скорости ветра ниже 2 м/с пыль осаждается на земной поверхности, закрепляясь на стеблях и листьях растений, шероховатой поверхности и др.
С целью определения вещественного состава и интенсивности накопления взвешенных частиц в воздушном потоке нами начаты наблюдения с использованием метода, предложенного M. Reheis [6] осенью 2013 г. Пылеуловители, расположенные на высоте 2 м над поверхностью земли, устанавливались в разных урочищах: лесополоса, кедровый лес, наветренные склоны пашни, и периодически очищались.

В данной статье анализируется содержание некоторых из определяемых тяжелых металлов в твердом осадке из пылеуловителей и снеговой воды, отобранных в 2017 г. Наблюдения за поступлением выпадений из атмосферы в пылеуловителях определялась в период с 22 мая по 31 августа, а снежной толще и на его поверхности с момента установления устойчивого снежного покрова до отбора проб 15 марта. Таким образом, были зафиксированы атмосферные выпадения в разные времена года.

Установлено, что пробы осадка пылеуловителей в лесополосах вблизи с. Лучаново и Плотниково характеризуются повышенными концентрациями свинца, меди и особенно цинка по сравнению с пробами твердого осадка снега в этих же участках (рис. 3). Возможно, что пылевое загрязнение атмосферного воздуха в летний период обусловлено трансграничным переносом загрязняющих веществ от источников выбросов предприятий, расположенных в соседних промышленных регионах (Новосибирская, Кемеровская области).

Наблюдения за накоплением эолового осадка позволили на данное время выявить неравномерное осаждение пыли в разных урочищах. 


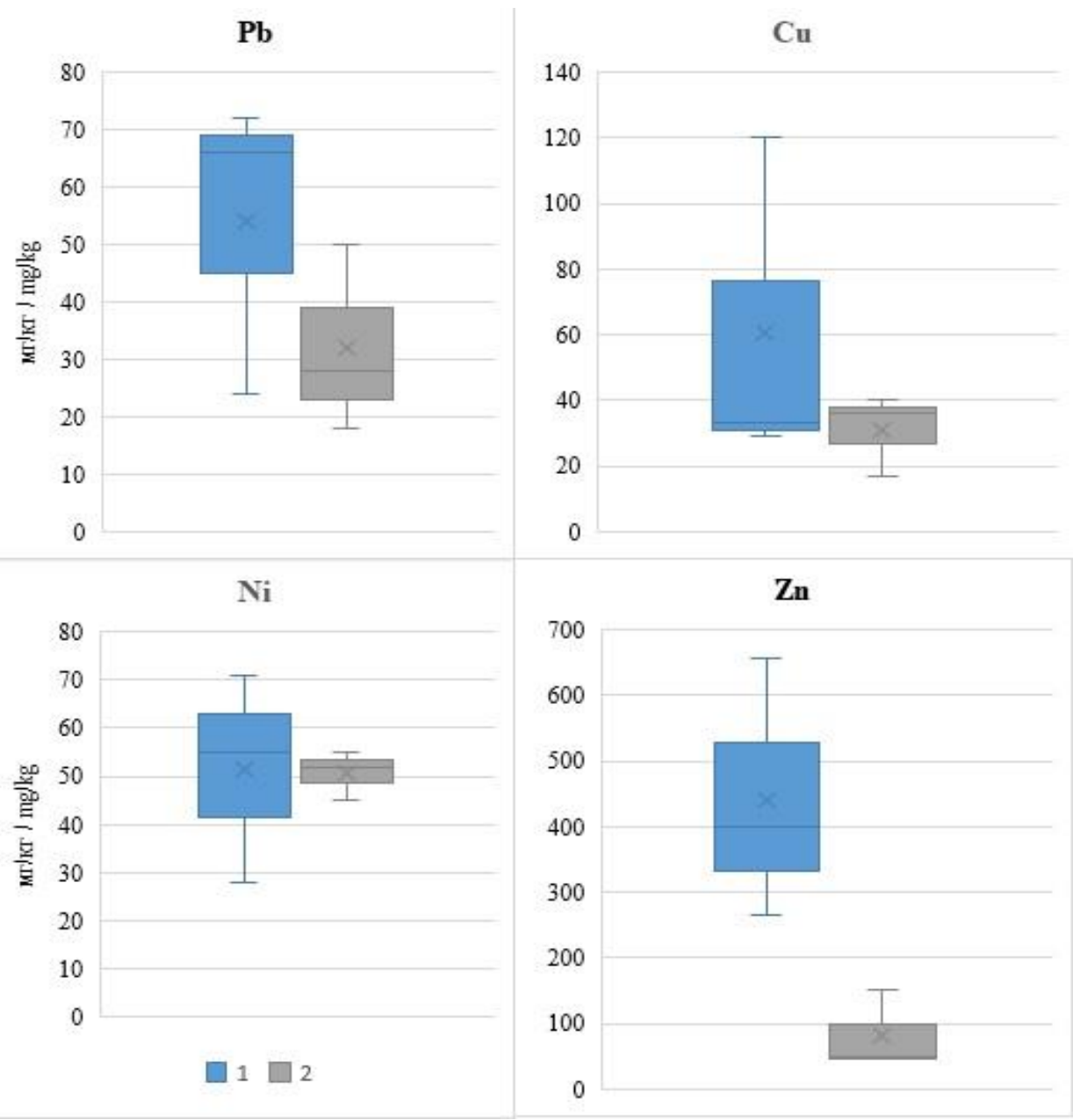

Pис. 3. Содержание химических элементов в осадке исследуемого района: 1 - пылеуловителей (июнь-август), 2 снежной толщи и на поверхности снега (ноябрь-март) 2017 г.

Fig. 3. Content of chemical elements in deposits within the study area (2017): 1 -from dust traps (June-August), 2 -from snow mass and the surface of the snow surface (November-March)

Менее всего эолового материала накапливается в пылеуловителях на наветренных склонах пашни как за период устойчивого залегания снежного покрова, так и за отдельные отрезки времени (табл. 5).

Интенсивность осаждения эолового осадка на высоте 2 м над поверхностью земли как в холодное, так и в теплое время года за период наблюдений в пределах 1 г/м² сутки, редко более (май-август 2017 г.), что значительно меньше интенсивности аккумуляции в толще снега и на его поверхности. Примеры вещественного состава осадка из пылеуловителей, уста- новленных в пределах ключевого участка в районе с. Лучаново, отражены на рис. 4.

В отложениях пылеуловителя, установленного на наветренном склоне пашни, хорошо различимы минеральные частицы округлой формы бледно-желтого цвета и бесформенные темного цвета (рис. 4, a). По сравнению с отложениями в пылеуловителе, установленном в кедровом лесу, здесь гораздо меньше частиц органического происхождения: остатков насекомых (крылышки, лапки и др.) и семян растений (рис. 4,6$)$.

Таблица 5. Примеры накопления эолового осадка в пылеуловителях

Table 5. Examples of aeolian deposits accumulation in dust traps

\begin{tabular}{|c|c|c|}
\hline Место отбора проб/Sampling place & $\begin{array}{l}\text { Сроки наблюдения, годы } \\
\text { Observation periods, years } \\
\end{array}$ & $\begin{array}{c}\text { Интенсивность аккумуляции, г/м²/сутки } \\
\text { Accumulation intensity, g/m²/day }\end{array}$ \\
\hline Наветренный склон пашни в районе с. Лучаново & $14.10 .2014-14.03 .2015$ & 0,03 \\
\hline Windward slope of the arable land near the village Luchanovo & 21.03.2015-07.05.2015 & 0,06 \\
\hline \multirow{3}{*}{$\begin{array}{l}\text { Лесополоса из сосны в районе с. Лучаново } \\
\text { Pine forest belt near the village Luchanovo }\end{array}$} & $14.10 .2014-14.03 .2015$ & 0,03 \\
\hline & 21.03.2015-07.05.2015 & 0,08 \\
\hline & $31.08 .2017-30.10 .2017$ & 0,19 \\
\hline $\begin{array}{l}\text { Лесополоса из березы в районе с. Плотниково } \\
\text { Birch forest belt near the village Plotnikovo }\end{array}$ & $22.05 .2017-31.08 .2017$ & 1,66 \\
\hline $\begin{array}{l}\text { Кедровый лес у с. Лучаново } \\
\text { Cedar forest near the village Luchanovo }\end{array}$ & $16.03 .2019-14.09 .2019$ & 0,20 \\
\hline
\end{tabular}



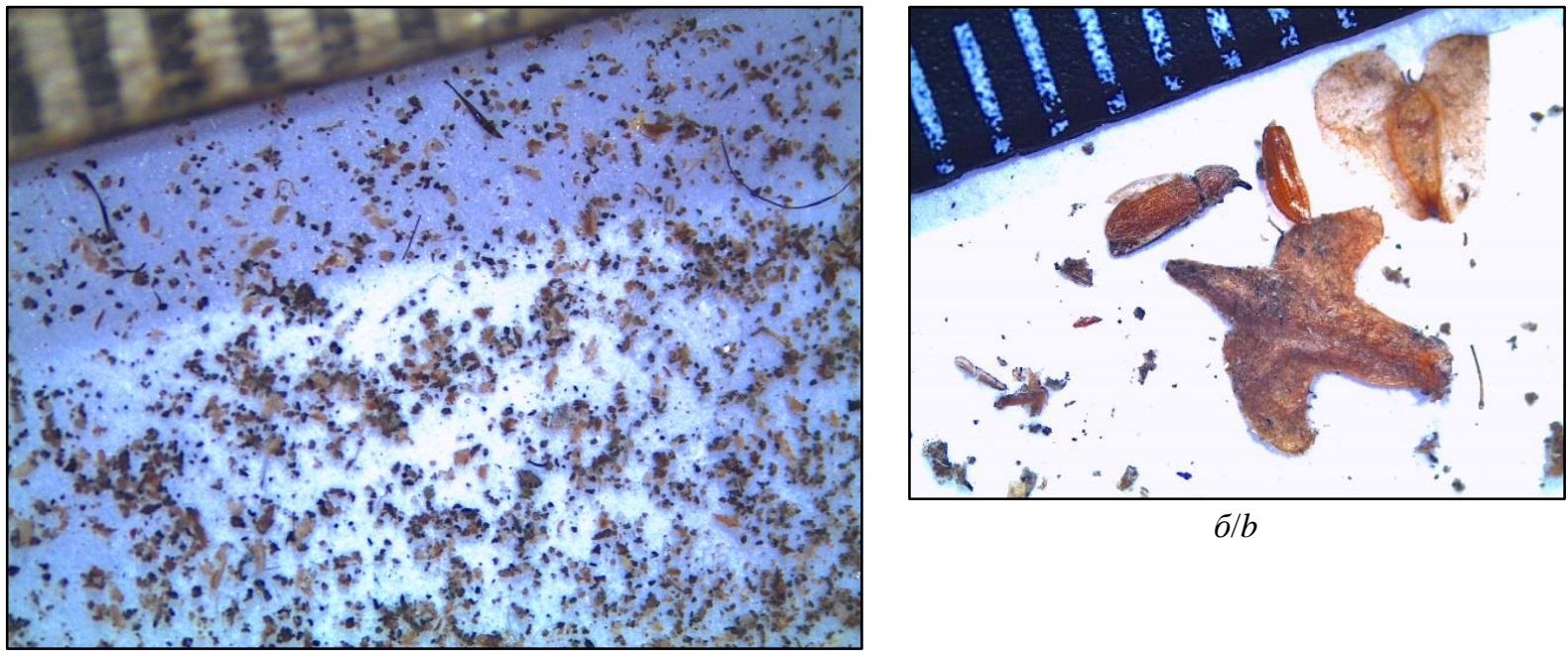

a/a

Pис. 4. Фотография образиов осадка из пылеуловителей исследуемого района: а) на пашне, 16-кратное увеличение; б) кедрового леса, 30-кратное увеличение (под оптическим микроскопом Leica EZ4D) (фото Е.Г. Язикова, 2019)

Fig. 4. Pictures of deposit samples from dust traps within the study area: a) on the arable land (x16); $b)$ in the cedar forest (x30, optical microscope Leica EZ4D) (photo by E.G. Yazikov, 2019)

Исследование методом РФА показало, что основу минералогического состава отложений в пылеуловителе, снежной толще и верхних горизонтах почв исследуемого района составляют кварц и мусковит (рис. 5), содержание которых достигает 87,1 \%. Полевые шпаты представлены в основном альбитом от 4,6 до $32 \%$, тогда как калиевый полевой шпат (ортоклаз) присутствует только в одном изучаемом образце - пылеуловителе, установленном на пашне, и составляет $10 \%$. Известковый шпат - кальцит, зафиксирован также в одном образце, в толще снега кедрового леса, и его содержание составляет 3,5 \%. Глинистые минералы в исследуемых образцах не обнаружены.

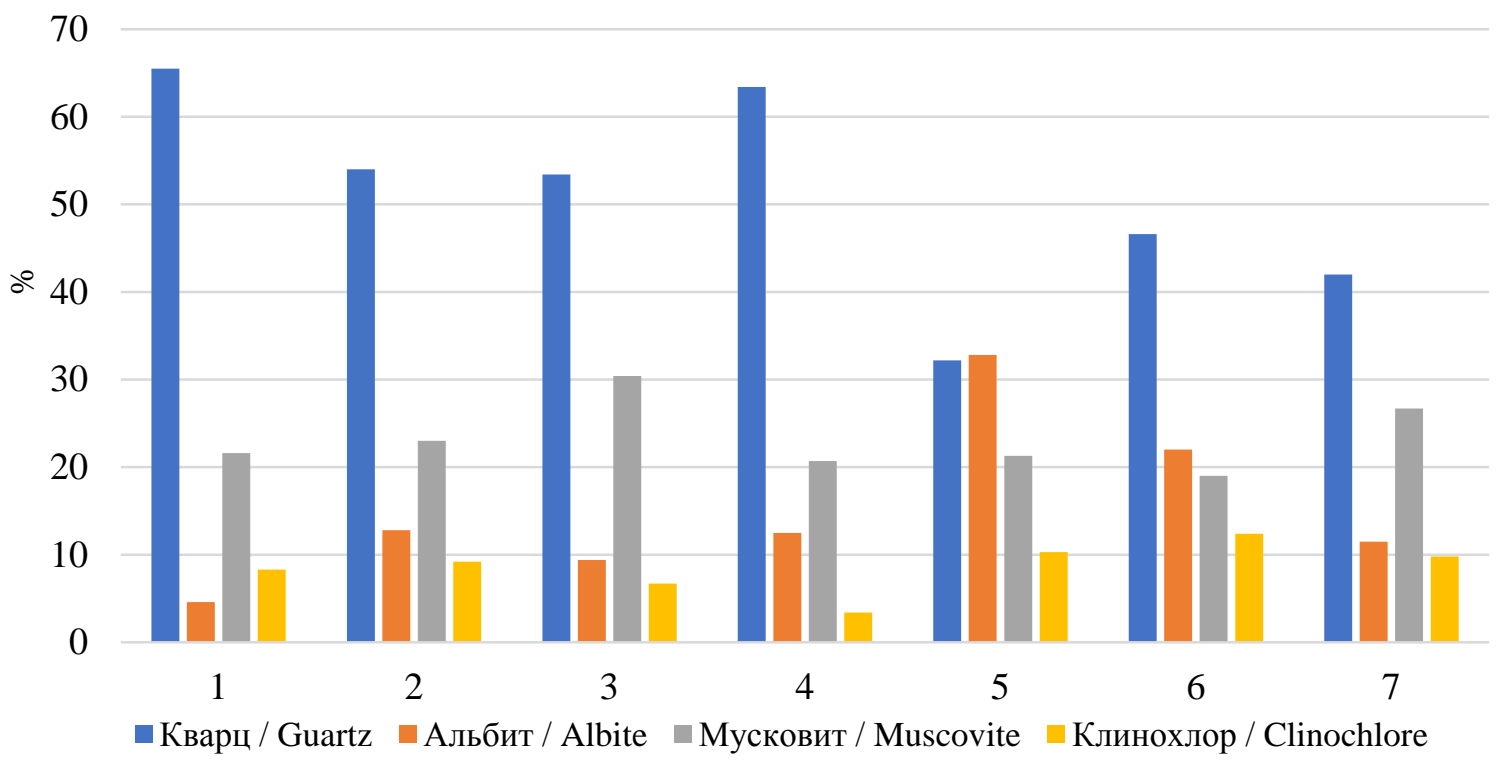

Pис. 5. Общий минералогический состав в исследуемых пробах ключевого участка: верхний горизонт почвы: 1 пашня, 2 - кедровый лес под пылеуловителем, 3-4-лесополоса; эоловые отложения: 5 - в толще снега, 6 - 6 пылеуловителе кедрового леса, 7 - в пылеуловителе в лесополосе

Fig. 5. Mineral composition of the studied samples within the key area: topsoils of: 1 - arable land, 2 - cedar forest with a dust trap, 3-4-forest belts; aeolian deposits of: 5 - snow mass, 6 - dust trap in the cedar forest, 7 - dust trap in a forest belt

Нами зафиксировано, что с высотой в почвоветровом потоке содержание пылеватых и илистых частиц возрастает и увеличивается содержание гумуса и дру- гих элементов питания растений [22]. В осадке пылеуловителя, установленного в лесополосе из сосны близ с. Лучаново, содержание гумуса до $10,5 \%$, что 
значительно превышает его концентрацию в верхних слоях почв пашни, разделенных этой лесополосой. В верхних горизонтах почвы лесополосы содержание гумуса достигает $9 \%$.

\section{Заключение}

Наши 32-летние наблюдения показывают, что в холодный период года эоловые процессы в агроландшафтах юго-востока лесной зоны ЗападноСибирской равнины проявляются ежегодно, но с разной степенью интенсивности. Наиболее активно они развиваются в малоснежные годы. За период 1989 2019 гг. очень сильная аккумуляция эолового осадка в снежной толще (500-1000 г/м) отмечалась в $10 \%$ случаев; сильная (200-500) - в 26,7 \% случаев; средняя (100-200) - в $10 \%$; умеренная (50-100) - в $10 \%$ и слабая (менее 50) - в 43,3 \%. Весьма активен этот процесс во время снеготаяния, когда за одни сутки в

\section{СПИСОК ЛИТЕРАТУРЫ}

1. Пустыня Гоби удобряет Калифорнию // Наука и жизнь. 2017. № 7. URL: https://www.nkj.ru/archive/articles/31704/ (дата обращения 10.01.2020)

2. Pan Y.P., Wang Y.S. Atmospheric wet and dry deposition of trace elements at 10 sites in Northern China // Atmospheric Chemistry and Physics. - 2015. - V. 15. - P. 951-972.

3. Говорушко С.М. Эоловые процессы и их роль в жизни общества // Геоморфология. - 2007. - № 3. - С. 37-45.

4. Bagnold R.A. The physics of Blown sand and desert dunes. London: Methuen, 1941. - $265 \mathrm{p}$.

5. Mellor M. Cold regions science and engineering. P. II. Blowing snow. - Hanover: CRREL Publ., 1965. - 78 p.

6. Reheis M.S. Dust deposition in Nevada, California, and Utah, 1984-2002 // U.S. Geological Survey. 2003. URL: http://pubs.usgs.gov/of/2003/ofr-03-138/ (дата обращения 15.02.2020).

7. Dust deposition near an eroding source field / L.J. Hagen, S. Van Pelt, T.M Zobek, A. Retta // Earth Surface Processes and Landforms. - 2007. - V. 32. - P. 281-289

8. Lancaster N. Aeolian features and processes // Geological Monitoring. - Boulder: Geological Society of America, 2009. - P. 1-25.

9. Munroe J.S. Properties of modern dust accumulating in the Uinta Mountains, Utah, USA, and implications for the regional dust system of the Rocky Mountains // Earth Surface Processes and Landforms. - 2014. - V. 39. - P. 1979-1988.

10. Сажин А.Н., Васильев Ю.И. Географические закономерности современной дефляции в степях Восточной Европы и Западной Сибири // Геоморфология. - 2003. - № 1. - С. 79-82.

11. Эоловый морфолитогенез и современный климат Евразии (ст. 1. Динамика атмосферы, блокируюшие и эоловые процессы) / А.Н. Сажин, Ю.И. Васильев, В.П. Чичагов, Г.А. Ларионов // Геоморфология. - 2012. - № 3. - С. 10-20.

12. Эоловый морфолитогенез и современный климат Евразии (ст. 2. Катастрофические эоловые процессы, динамические различия эоловых процессов современной и ледниковой эпох) А.Н. Сажин, Ю.И. Васильев, В.П. Чичагов, Г.А. Ларионов // Геоморфология. - 2013. - № 2. - С. 3-14.

13. Лессовый покров Земли и его свойства / В.Т. Трофимов, С.Д. Балыкова, Н.С. Болиховская, Т.В. Андреева, Б.А. Алексеев, В.Ф. Болиховский, А.Е. Додонов, Ю.Г. Ермаков, А.В. Ершова, Э.В. Кадыров, Т.А. Ковалева, Т.И. Кондратьева, Е.Ю. Любимцева, А.В. Минервин, С.Г. Миронюк. - М.: Изд-во Моск. ун-та, 2001. -464 с.

14. Бельгибаев М.Е. Типология эоловых процессов и их влияние на геосферы и ландшафты // Материалы XXXV Пленума Геоморфологической комиссии РАН. - Симферополь, 2016. T. 1. - C. $15-20$.

15. Кадастр возможностей / А.М. Данченко, Г.О. Задде, А.А. Земцов, В.А. Земцов, Л.И. Инишева, Б.В. Лукутин, эоловых волнах местами накапливается до 23,6 г/м наноса, а за 3 суток - 224,5 г/м. Таким образом, в агроландшафтах холодного периода года возможно возникновение местных пыльных бурь весной.

В гранулометрическом составе эолового наноса преобладает пыль, в минералогическом - кварц и мусковит. Эоловые отложения содержат значительное количество элементов питания растений - гумуса - до $10 \%$

Не исключая притока атмосферных выпадений, обусловленных антропогенной деятельностью, в том числе и близлежащих регионов [23-26], считаем, что основная масса эолового осадка ключевых участков (юго-восток Томской области) в холодное время года имеет локальное происхождение, об этом свидетельствует большое сходство его гранулометрического, химического и минералогического состава с почвами региона.

А.В. Мезенцев, С.Г. Маслов, А.Д. Назаров, С.Г. Обухов, В.В. Севастьянов, Л.М. Севастьянова, В.И. Слуцкий. - Томск: Изд-во НТЛ, 2002. -280 с.

16. Середина В.П., Спирина В.В. Почвообразование в подтаежной зоне Западной Сибири. - Томск: Изд-во НТЛ, 2005. - 284 с.

17. Современный эоловый морфолитогенез холодного периода года на юго-востоке зоны подтайги Западно-Сибирской равнины / Н.С. Евсеева, 3.Н. Квасникова, М.А. Каширо, А.С. Батманова // Геосферные исследования. - 2017. - № 2. C. 6-13.

18. Евсеева Н.С., Безгодова О.В. Оценка дефляционной опасности почв лесной зоны юго-востока Западно-Сибирской равнины // Индикация состояния окружающей среды: теория, практика, образование. Труды шестой международной научнопрактической конференции. - М.: Буки-Веди, 2018. C. 263-268.

19. Аристархова Л.Б. Эоловые процессы и морфолитогенез // Динамическая геоморфология / под ред. Г.С. Ананьева, Ю.Г. Симонова, А.И. Спиридонова. - М.: Изд-во МГУ, 1992. C. $323-351$

20. Гендугов В.М., Глазунов Г.П. Ветровая эрозия почв и запыление воздуха. - М.: ФИЗМАТЛИТ, 2007. -240 с

21. Кальянов К.С. Динамика процессов ветровой эрозии почвы. М.: Наука, 1976. $-143 \mathrm{c}$.

22. Скорости седиментации эоловой пыли в лесополосах на пашне подтайги юго-востока Западно-Сибирской равнины / Н.С. Евсеева, 3.Н. Квасникова, А.С. Батманова, М.А. Каширо, В.В. Назаров, О.Э. Мерзляков // Географический вестник. 2016. - № 3 (38). - C. 5-15.

23. Mezhibor A.M., Arbuzov S.I., Rikhvanov L.P. Accumulation and average contents of trace elements in the high-moor peat of Tomsk region (Western Siberia, Russia) // Energy Exploration and Exploitation. - 2009. - V. 27 (6). - P. 401-410.

24. Bolshunova T.S., Rikhvanov L.P., Mezhibor A.M. Epiphytic lichens as indicators of air pollution in Tomsk Oblast (Russia) // IOP Conference Series: Earth and Environmental Science. 2014. - V. 21. -012043 .

25. Characterization of solid airborne particles deposited in snow in the vicinity of urban fossil fuel thermal power plant (Western Siberia) / A.V. Talovskaya, E.G. Yazikov, E.A. Filimonenko, J.-C. Lata, J. Kim, T.S. Shakhova // Environmental Technology (United Kingdom). - 2018. - V. 39. - Iss. 18. - P. 2288-2303.

26. Comparative estimation of geochemical activity of the atmosphere according to the ratio of compositions of different near-ground aerosol fractions at the fonovaya observatory in Autumn 2016 / B.D. Belan, D.V. Simonenkov, A.V. Talovskaya, M.P. Tentyukov, A.V. Fofonov, E.G. Yazikov // Atmospheric and Oceanic Optics. 2018. - V. 31. - Iss. 1. - P. 36-42.

Поступила 15.10.2020 г. 


\section{Информация об авторах}

Eвсеева H.C., доктор географических наук, заведующая кафедрой географии геолого-географического факультета Национального исследовательского Томского государственного университета.

Язиков Е.Г., доктор геолого-минералогических наук, профессор отделения геологии Инженерной школы природных ресурсов Национального исследовательского Томского политехнического университета.

Квасникова 3.Н., кандидат географических наук, доцент кафедры географии геолого-географического факультета Национального исследовательского Томского государственного университета.

Батманова A.C., ассистент кафедры географии геолого-географического факультета Национального исследовательского Томского государственного университета.

Бучельников В.С., аспирант Отделения геологии Инженерной школы природных ресурсов Национального исследовательского Томского политехнического университета. 
UDC 551.4.042+551.4.022+559.462

\section{PRESENT-DAY AEOLIAN MORPHOLITHOGENESIS: STATE OF KNOWLEDGE AND REGIONAL MANIFESTATIONS}

Nina S. Evseyeva1, nsevseeva@yandex.ru

Egor G. Yazikov², yazikoveg@tpu.ru

Zoya N. Kvasnikova1, zojkwas@rambler.ru

\section{Antonina S. Batmanova ${ }^{1}$,} tonu6ka@yandex.ru

Viktor S. Buchelnikov², victor.buchelnikov@yandex.ru

1 National Research Tomsk State University, 36, Lenin avenue, Tomsk, 634050, Russia.

2 National Research Tomsk Polytechnic University, 30, Lenin avenue, Tomsk, 634050, Russia.

The relevance of the research of exogenous processes, including deflation, is caused by both positive and negative impact of the processes on landscape components and economic activity. Besides, features of regional material migration under the action of aeolian processes, the accumulation intensity of deposits, and their material composition are poorly understood. Environmental conditions and anthropogenic impact cause the development of wind erosion and deflation in geosystems of Tomsk region.

The main aim of this study is to estimate accumulation intensity of aeolian deposits and determine its material composition for the landscapes in the southeast of Tomsk region.

Objects of the research are natural and anthropogenic landscapes of the Tom-Yaya interfluve within the Basandayka river basin (the right tributary of the Tom river).

Methods: field measurements with sampling, laboratory analyses, analytical studies.

Results of the study have revealed based on long-term observations that aeolian processes in the agricultural landscapes of the southeast of the forest zone in the West Siberia appear annually. The intensity of the processes has a variety from year to year and reaches the maximum values in dry winters. Dust prevails in the grain size distribution of aeolian deposits. Quartz and muscovite are dominant in total mineral composition. Aeolian deposits contain a significant amount of plant nutrients (humus - up to $10 \%$ ) in many cases. The authors consider that the bulk of the aeolian deposits within the key area (southeast of the Tomsk region) in the cold season has a local origin. The strong similarity of the grain size distribution, chemical and mineral compositions of deposits with soils of the area are indicative of that.

Key words:

Deflation, aeolian processes, Tomsk region, Tom-Yaya interfluve, dust trap, arable land.

\section{REFERENCES}

1. Pustynya Gobi udobryaet Kaliforniyu [The Gobi Desert fertilizes California]. Nauka $i$ zhizn, 2017, vol. 7. Available at: https://www.nkj.ru/archive/articles/31704/ (accessed 10 January 2020).

2. Pan Y.P., Wang Y.S. Atmospheric wet and dry deposition of trace elements at 10 sites in Northern China. Atmospheric Chemistry and Physics, 2015, vol. 15, pp. 951-972.

3. Govorushko S.M. Aeolian processes and their role in human conditions. Geomorfologiya, 2007, no. 3, pp. 37-46. In Rus.

4. Bagnold R.A. The phisics of Blown sand and desert dunes. London, Methuen, 1941. $265 \mathrm{p}$.

5. Mellor M. Cold regions science and engineering. P. II. Blowing snow. Hanover, CRREL Publ., 1965.78 p.

6. Reheis M.S. Dust deposition in Nevada, California, and Utah, 1984-2002. U.S. Geological Survey. 2003. Available at: http://pubs.usgs.gov/of/2003/ofr-03-138/ (accessed 15 February 2020).

7. Hagen L.J., Van Pelt S., Zobek T.M., Retta A. Dust deposition near an eroding source field. Earth Surface Processes and Landforms, 2007, vol. 32, pp. 281-289.

8. Lancaster N. Aeolian features and processes. Geological Monitoring. Boulder, Geological Society of America, 2009. pp. 1-25.
9. Munroe J.S. Properties of modern dust accumulating in the Uinta Mountains, Utah, USA, and implications for the regional dust system of the Rocky Mountains. Earth Surface Processes and Landforms, 2014, vol. 39, pp. 1979-1988.

10. Sazhin A.N., Vasilev Yu.I. Geograficheskie zakonomernosti sovremennoy deflyatsii v stepyakh Vostochnoy Evropy i Zapadnoy Sibiri [Geographic patterns of modern deflation in the steppes of Eastern Europe and West Siberia]. Geomorfologiya, 2003, no. 1, pp. 79-82.

11. Sazhin A.N., Vasilev Yu.I., Chichagov V.P., Larionov G.A. Eolian morphogenesis and recent climate of Eurasia (paper 1. Atmosphere dynamics, blocking and eolian processes). Geomorfologiya, 2012, no. 3, pp. 10-20. In Rus.

12. Sazhin A.N., Vasilev Yu.I., Chichagov V.P., Larionov G.A. Eolian morphogenesis and recent climate of Eurasia (paper 2. Disastrous eolian processes, dynamic differences of eolian processes in recent and glacial epochs). Geomorfologiya, 2013, no. 2, pp. 3-14. In Rus.

13. Trofimov V.T., Balykova S.D., Bolikhovskaya N.S., Andreeva T.V., Alekseev B.A., Bolikhovskiy V.F., Dodonov A.E., Ermakov Yu.G., Ershova A.V., Kadyrov E.V., Kovaleva T.A., Kondratyeva T.I., Lyubimtseva E.Yu., Minervin A.V., Mironyuk S.G. Lessovy pokrov Zemli i yego svoystva [Loess cover of the Earth and its properties]. Moscow, Moscow University Press, 2001. $464 \mathrm{p}$. 
14. Belgibaev M.E. Tipologiya eolovykh protsessov i ikh vliyanie na geosfery i landshafty [Typology of aeolian processes and their impact on geospheres and landscapes]. Materialy XXXV Plenuma Geomorfologicheskoy komissii RAN [Materials of the XXXV Plenum of the Geomorphological Commission of the RAS]. Simferopol, 2016. Vol. 1, pp. 15-20.

15. Danchenko A.M., Zadde G.O., Zemtsov A.A., Zemtsov V.A., Inisheva L.I., Lukutin B.V., Mezentsev A.V., Maslov S.G., Nazarov A.D., Obukhov S.G., Sevastyanov V.V., Sevastyanova L.M., Slutskiy V.I. Kadastr vozmozhnostey [Cadastre of opportunities]. Tomsk, NTL Publ. house, 2002. 280 p.

16. Seredina V.P., Spirina V.V. Pochvoobrazovanie v podtaezhnoy zone Zapadnoy Sibiri [Soil formation at the subtaiga zone of Western Siberia]. Tomsk, NTL Publ. house, 2005. 284 p.

17. Evseyeva N.S., Kvasnikova Z.N., Kashiro M.A., Batmanova A.S Modern aeolian morpholithogenesis of cold period in the SouthEast part of the Sub-Taiga Zone of the West Siberian Plain. Geo sphere Research, 2017, no. 2, pp. 6-13. In Rus.

18. Evseyeva N.S., Bezgodova O.V. Otsenka deflyatsionnoy opasnosti pochv lesnoy zony yugo-vostoka Zapadno-Sibirskoy ravniny [Assessing of soil deflation danger at forest zone in the southeast of the West Siberia Plain]. Indikatsiya sostoyaniya okruzhayushchey sredy: teoriya, praktika, obrazovaniye. Trudy shestoy mezhdunarodnoy nauchno-prakticheskoy konferentsii [Indication of the state of the environment: theory, practice, education. Proceedings of the sixth international scientific and practical conference]. Moscow, Buki-Vedi, 2018. pp. 263-268.

19. Aristarkhova L.B. Eolovye protsessy i morfolitogenez [Aeolian processes and morpholithogenesis]. Dinamicheskaya geomorfologiva [Dynamic geomorphology]. Moscow, MGU Publ. house, 1992. pp. 323-351.
20. Gendugov V.M., Glazunov G.P. Vetrovaya eroziya pochv $i$ zapylenie vozdukha [Soil wind erosion, and air dust pollution]. Moscow, FIZMATLIT Publ., 2007. 240 p.

21. Kaliyanov K.S. Dinamika protsessov vetrovoy erozii pochvy [Dynamics of wind erosion of the soil]. Moscow, Nauka Publ., 1976. $142 \mathrm{p}$.

22. Evseyeva N.S., Kvasnikova Z.N., Batmanova A.S., Kashiro M.A., Nazarov V.V., Merzlyakov O.E. Sedimentation rate of aeolian dust in woodland belts on arable land of the sub-boreal forest in the southeast part of the West Siberian plain. Geograficheskiy vestnik, 2016, no. 3, pp. 5-15. In Rus.

23. Mezhibor A.M., Arbuzov S.I., Rikhvanov L.P. Accumulation and average contents of trace elements in the high-moor peat of Tomsk region (Western Siberia, Russia). Energy Exploration and Exploitation, 2009, vol. 27, no. 6, pp. 401-410. In Rus.

24. Bolshunova T.S., Rikhvanov L.P., Mezhibor A.M. Epiphytic lichens as indicators of air pollution in Tomsk Oblast (Russia). IOP Conference Series: Earth and Environmental Science, 2014, vol. 21, 012043 .

25. Talovskaya A.V., Yazikov E.G., Filimonenko E.A., Lata J.-C, Kim J., Shakhova T.S. Characterization of solid airborne particles deposited in snow in the vicinity of urban fossil fuel thermal power plant (Western Siberia). Environmental Technology (United Kingdom), vol. 39, Iss. 18, pp. 2288-2303.

26. Belan B.D., Simonenkov D.V., Talovskaya A.V., Tentyukov M.P., Fofonov A.V., Yazikov E.G. Comparative estimation of geochemical activity of the atmosphere according to the ratio of compositions of different near-ground aerosol fractions at the fonovaya observatory in Autumn 2016. Atmospheric and Oceanic Optics, 2018, vol. 31, Iss. 1, pp. 36-42.

\section{Information about the authors}

Nina S. Evseyeva, Dr. Sc., professor, National Research Tomsk State University.

Egor G. Yazikov, Dr. Sc., professor, National Research Tomsk Polytechnic University.

Zoya N. Kvasnikova, Cand. Sc., associate professor, National Research Tomsk State University.

Antonina S. Batmanova, assistant, National Research Tomsk State University.

Viktor S. Buchelnikov, postgraduate student, National Research Tomsk Polytechnic University. 